\title{
The Political Representation of Women in Mass Media Discourse in the Czech Republic 1990-1998
}

\author{
HANA HAVELKOVÁ* \\ Institute of Humanities, Charles University, Prague
}

\begin{abstract}
In the Czech Republic the issue of the political participation of women has particular significance as the question that has opened up public discussion of the public status of women, perceived by the general public as the most conspicuous area of gender inequality of opportunity since 1989. The absence of discussion of the question under the communists meant that post-1989 debate has had to start 'from scratch', and so the article analyses the role of various categories of intelligentsia in establishing the terms of public discourse as well as considering specific and general perceptions of the gender dimension of Czech politics and gender stereotypes in the context of politics. The source materials are articles explicitly dealing with the subject in the major Czech dailies and selected magazines, and the article presents a typology of the attitudes embodied in these articles and classification of their authors in terms of profession, sex, age and political affiliations. This research confirms that media workers are weak in their response to public opinion and use of experts, and are principally aligned with attitudes directly derived from the sphere of politics. In relation to the issue of the political representation of women, the media has affected public discourse by both opening it and, paradoxically, blocking it. Nevertheless, gender stereotypes themselves have been undergoing special modifications in the context of political representation.

Czech Sociological Review, 1999, Vol. 7 (No. 2: 145-165)
\end{abstract}

This article is an extract from a hundred-page study written in Czech as part of a research project that I carried out in $1996-98 .{ }^{* *}$ What is presented here is only part of an analysis of media discourse. The sections on academic and feminist discourse have been omitted, together with the analysis of interviews with women politicians, an account of trends in public opinion on this question over the period concerned, and most of the theoretical discussion.

\section{Theme}

My empirical starting point for analysis of this subject is the surprising reaction of the Czech public to the very low representation of women in politics since 1989. It has become apparent that while the Czech public was very well aware that the $30 \%$ share of parliamentary seats occupied by women under communism was a mere formality, it was nonetheless surprised at the fall in this share to $10 \%$ after 1989 when the quotas were abolished, and regards the current $15 \%$ proportion of women deputies in the lower house of parliament as unsatisfactory. This percentage is slightly under the average for the countries of the European Union [Hoecker 1998] where certain other countries have

\footnotetext{
*) Direct all correspondence to: PhDr. Hana Havelková, Institute of Humanities, Charles University, Legerova 63, 12000 Praha 2, e-mail havelkov@sun.izv.cuni.cz

${ }^{* *}$ ) Carried out with support from the Research Support Scheme of the OSI/HESP, grant No. $1298 / 1996$.
} 
lower percentages, and after the Baltic states it is in fact the highest percentage for countries of the former Soviet bloc. In this context, the public expression of dissatisfaction constitutes important information from the point of view of gender-relevant political culture, since it reflects a certain level of social expectations of equality in relation to sexual equality in the political field. The public has also begun to regard politics as an area where the whole social transformation is turning out to benefit men rather than women, and it is in fact one of the first areas in which there is a serious public perception of undesirable gender differentiation. The problem of the political representation of women has thus become one of the first gender orientated themes to be taken up by the Czech media, and it is therefore a theme that allows us to uncover what have been previously publicly unvoiced gender stereotypes in Czech society.

Public opinion surveys and the analyses presented here suggest that perceptions of gender differentiation, in relation to politics, may be identified on four levels. First, there is the already mentioned general dissatisfaction with gender asymmetry in politics. Second, there is ever deeper differentiation between men's and women's opinions as far as acceptance of this situation is concerned (a radicalisation of the female population). Third, a strikingly gendered perception of post-1989 politicians has emerged, with the crystallisation of a very distinctive image of the male post-1989 politician on the one hand, and on the other a projection of the qualities of the ideal female politician. Fourth, analysis of media discussion on the subject has shown clear differentiation between men and women in terms of their imaginative capacity to consider the importance of women in politics or the specific agenda that women might bring to politics.

It is obviously necessary to explain why the research has been focused on the analysis of mass media texts, since in Western countries the question of the representation of women in politics is not as closely linked as it is in the Czech Republic with expectations of media treatment of the subject. The reason is to be found in the specific character of a society undergoing a transformation in which certain kinds of cultural awareness and public discourse are having to develop from 'point zero', and the civic sector as a whole, women's activism, and even academic studies in the field of gender have also had to emerge 'from scratch'. We must therefore take into account the entirely non-standard and unprecedented situation, in which the media have for years been operating in the unbalanced context of hypertrophied interest in the political scene on the one side, and an almost complete vacuum on the side of the civic sector. This means that in contrast to that of the western countries, the emerging discourse has not been developing out of women's activation and a women's movement. It has not, in other words, been an expression of grassroots change, but simply a part of a general revival of self-conscious reflection on the state of society. As in other areas, the public status of women had been evolving over the long communist period without being the subject of public reflection or focused cultural and political debate and action. We should also remember that even after 1989, the first, and in fact the only discussion organised by women's groups on the question of the political representation of women, like the first publication on this theme, occurred as late as 1996. As far as the political scene itself is concerned, the pressure of internal party women's sections also continues to be weak, since where they exist they do not make the goal of a higher percentage of women in top political bodies a priority. In Czech society we are currently witnessing a curious situation, in which on the one hand public opinion is making relatively strong calls for the increased political representation of women while on the other the political structures are inert, and can afford to ignore these calls mainly 
because women's groups are applying almost no organised pressure. In these circumstances the media remains as it were the only 'playing field' for contests about the legitimisation of the political representation of women, and in the hypertrophied role of a mediator on which society nevertheless relies, it can have a marked positive or negative influence on the development of discussion.

Analysis of media texts has shown that in the emergent Czech discussions on women in politics, the main problem has not been any clash between feminist and conservative sections of society (representatives of these sections have shown little engagement in the issue), but rather the inconsistency, lack of consequence, and surprisingly monologic character of the very forms of the 'discussion'. As a result, a theme that I originally regarded as secondary - the role of the mass media as mediator, middle man and initiator of the development of civic discourse and civic society - has come to the fore in the course of the research. Analysis of the explicit relationship of media workers and other media actors to public opinion, their use of expert opinion and their relationship to the political scene, proved to be especially fruitful. Analysis of the course and character of media discussion on the theme of women in politics thus made it possible, in an extremely concrete way, to document several dysfunctional and blocking mechanisms of media work in relation to public discourse, and to confirm the idea that the dominance of the political scene and weak position of the civic sector leads to similar asymmetry in media discourse.

\section{Theoretical Hypotheses}

In this article the theoretical starting points can be set out only in broad outline. It is clear that the situation in the Czech Republic and other post-communist countries contradicts one of the basic theses of western political science, according to which the key factor for a high political representation of women is female access to education, paid employment and experience in the professions that dominate in politics [see Matland 1999 or Voet 1998]. All these conditions (including a large number of women with legal and economics education) are fulfilled here, but without the anticipated effect in the field of politics. My initial hypothesis was to posit the existence of a cultural barrier based on the idea that there was a difference between social acceptance of women's employment outside the home (which in this country has become culturally almost taken for granted) and acceptance of women's right to decision-making about society as a whole. From the point of view of political philosophy, one could here apply the distinction between labour and work (basic types of human work) on the one hand, and action, i.e. political action as the supremely human activity [Arendt 1960], on which men have historically held the longest-standing monopoly. In Czech media discourse (i.e. publicly presented opinions of the intellectual elite), however, this hypothesis was not confirmed (although in the overall population approximately $22 \%$ still regard the current low level of political representation of women as appropriate and natural). The overwhelming majority of the media texts are strikingly inclined to female political representation and assert that men and women are equally politically competent. Reference is often made to the high qualifications and expert abilities of Czech women and it therefore seems that at this level the cultural barrier suggested no longer exists. At least on this intellectual level, in other words, there would appear to be confirmation of the political philosopher Voet's theory that any kind of participation by women in the public sphere, e.g. in the work sphere, is a preparation for the 
adoption of civic virtues and the condition for active or full citizenship in the Aristotelian sense [Voet 1980].

There are indications, however, of the existence of two types of cultural barrier that are, as it were, psychologically 'deeper' in nature. The first is the image of 'the Czech woman' as somehow 'above' any kind of formal battle with men over percentages, and as finding her social mission in 'other great things' such as love and sacrifice, obviously in the private sphere (for a typical example see Librová in [Buchert et al. 1995]). This attitude implies, among other things, the legitimisation of female indifference to politics, and a view of politics as a game that can be safely left to men, since men do not have traditional female privileges. Related to this is a second pattern, i.e. the expectation of traditional feminine behaviour among female politicians, paradoxically the more severely applied the higher the position that the female politician achieves. This is reflected in the differing media images that are being created around female parliamentary deputies on the one hand and female mayors on the other (the chapter on the image of female politicians has been omitted for reasons of space). Female politicians themselves not only seek to maintain their feminine image, but it appears that in many cases this image prevents them from rising higher in office (it is worth considering, for example, whether the defeat of Magda Vašáryová in her bid for the Slovak presidency was not partly a result of the way her feminine image was undermined by the general perception that she had been "too aggressive" in a television debate). Strikingly often, Czech women politicians stress that they do not care about high office, and only achieved it 'by chance'. We may therefore deduce that the specific hybrid traditionalist-communist model of the woman who is employed but has no high, and above all no open ambitions, is changing only very slowly. This barrier may be linked to a further cultural barrier arising from the fact that despite public acknowledgement of the expert qualifications of women, the main arguments in favour of higher representation of women are themselves based predominantly on traditional gender ascriptions and the associated demand that both 'halves of humanity', or their 'good' attributes (as ascribed by gender) should complement each other. As yet, there are no signs of the emergence of a different kind of image of political representatives, involving the idea that some (traditionally gender differentiated) attributes might be combined in one person. This means that even those who support the political representation of women are de facto demanding the application of traditional feminine attributes (caring and cultivating) even if outside the domestic sphere.

My second hypothesis derives from my conviction that arguments in favour of women's representation in politics will remain weak and ineffective until a specific female social and civic experience is identified and transformed into a political agenda [see, e.g. Havelková 1996a, b]. My analysis has strongly confirmed this hypothesis. One curious feature of the Czech situation is the fact that here discussion of the political representation of women has preceded discussion of the social position and real problems of contemporary women. In no western country have these two questions been disconnected in this way, and this disconnection is the result of the previous absence of public discourse. The consequence is that Czech discussion of women in politics has so far, with very few exceptions, been mainly abstract in character, focused much more on what women can do for politics than on what politics (and women in politics) can do for women. Moreover, the non-existence of a concrete political agenda has gradually led to the degeneration and, as it were, folklorisation of the whole discussion (even in the serious media), and a tendency to focus on such subjects as which female deputy deserves the 
title of beauty queen of parliament etc. [e.g. Pitrová 1998]. In the last two years such standard gender themes as 'women in the job market', domestic violence and so forth have begun to appear more frequently in the media, but so far without any links being made to the subject of women's lobbies and the importance of women in politics. The step to connecting these two areas in Czech media discourse has still to be made. In these circumstances it is, therefore, useful to distinguish between the question of the political participation of women and that of their political representation, i.e. the kind of participation related to the representation of the specific social interests of women.

With these theoretical structures in mind, I have focused successively on the following aspects of media discourse: the level of recognition of the potential political competence of women, the level of perception of their different civic experience and political goals, the perceived relevance of the political participation and representation of women to the quality of the democratic system, the gender image of men and women as it is articulated in relation to politics, and the extent to which this is allegedly based on culture (or convention), or on the current character of politics itself.

\section{Research Method}

In view of the non-standard character of the Czech situation as I have described it above, the empirical research has not been conducted by applying standard research approaches taken from the Western political or gender studies that are based on detailed monitoring not only of the numerical representation of women in a broad range of politically relevant bodies but also of the structures through which they exert real practical influence, their professional deployment in politics, and analyses of differences in the media appearances of male and female politicians etc.

The subject-matter of my analysis consists of articles in selected Czech print media that explicitly deal with the question of the political participation of women in this country and offer information on the situation in other countries. I have exhaustively analysed such articles in the newspapers Lidové noviny and Mladá fronta DNES (the largest circulation dailies with a liberal orientation), from 1990 to the end of 1998, i.e. for a period that includes all parliamentary elections so far held since 1989. This material has been augmented by articles from the weekly magazine supplements of the two papers mentioned and the weeklies Respekt, Týden and Reflex. Limited research time meant that I have not yet included the most important left-wing daily Právo, and this to a certain extent limits the degree to which my results can be generalised. Nor have I analysed the electronic media. Overall, approximately eighty articles of varying lengths were analysed.

The texts were analysed in a purely qualitative way. I placed the emphasis on detailed differentiation, creation of a typology and categorisation of the opinions, attitudes and arguments that they contained. The aim was not linguistic but sociological analysis, i.e. primarily the identification of social attitudes categorised according to the gender of the authors, their professions and political orientation, and also their age group where this could be identified. The breakdown of authors in terms of professions proved to be particularly useful since it showed the proportions in which media staff and other kinds of author are contributing to the discussion. The basic authorial categories used are journalists, politicians, experts (specific expertise stated), feminists and readers. It must be stressed that my analysis was concerned not merely with media practice, but also with the extent and way in which the Czech intelligentsia are creating this particular discourse, and the type of intellectual who enters into it. 
I considered the content of the texts from the point of the development of their thematic orientation in individual phases of the post-1989 transformation of Czech society, their use of expert opinion, the character of the ideological positions reflected in views of this particular theme and so on. The statements in the texts were analysed in terms of six categories created for this research project.

1. Statements justifying the relevance of the theme of women in politics.

2. Statements formulating the main reasons for the low representation of women in this country.

3. Arguments justifying the need for higher political representation of women in this country.

4. Statements relating to forms of active support for higher political representation of women in this country.

5. Presentations creating the media image of women politicians.

6. Commentaries creating the media image of women voters.

This classification itself shows the value of focusing on media texts rather than simply relying on public opinion polls. In relation to Category 1, such polls identify 'whether' the respondents regard this theme as relevant, but not 'why'. In relation to Category 2, they identify the basic catalogue of reasons put forward, but not the considerations in the background [Kalnická 1998]. For Category 4 they are only able to ascertain the extent of support for quotas, but not arguments for and against. The questions relating to Categories 3, 5 and 6 are not monitored by public opinion monitoring agencies at all. Within these categories, typologies of statements have then been developed on the basis of the material obtained. Category 3 deserves special attention since it is the category in which the issues go most significantly beyond the gender issue and statements reveal general views of the character of Czech politics, civic life and virtues, and suchlike.

The research has shown that the sociological analysis of texts would be much more effective if it also focused on the character of the connections (or formation of information channels) between the media public opinion, professional (expert) opinion and the political sphere. For this reason the media texts were supplemented as sources by a view of the main findings from other sources relating to the theme: public opinion polls, interviews with post-1989 women politicians, and specialist texts on the subject (using a gender approach) published outside the mass media. It is characteristic of the transformation period under study that these four areas of the creation of public discourse have so far developed more or less separately, and each has its own dynamic.

\section{The Development and Basic Characteristics of Media Discourse}

In the first post-revolutionary years the theme of women in politics was virtually absent from the media. Society was absorbed by such major and fundamental themes as the new constitution, charter of human rights, nationalism, privatisation, Czecho-Slovak relations, rehabilitation, the general moral atmosphere of society, return to Europe and so forth. The only voices raised on gender issues were from the Christian side, on the themes of abortion and motherhood. All published reactions on the representation of women vehemently denied the existence of sexual discrimination and rejected the idea of quotas. Politics (and especially economics) were regarded as entirely gender-neutral and it was assumed that men would automatically represent and deal with the problems of both sexes, and so the 
question of the representation of women was irrelevant. The turning-point came late in 1995 , when the theme caught media attention partly as a result of comparisons made with foreign countries (and not only with the advanced democracies), and partly as a reaction to public opinion polls. What was especially surprising was the change in public views of quotas, i.e. the high percentage of people who would approve of quotas in some form [Haberlová 1993]. The parliamentary elections in 1996 were the first to involve public focus on the question of the political participation of women. In the pre-election period in the spring of 1996 interest in this subject reached a peak, although it must be stressed that this was too late for public opinion to have influenced the results of the elections themselves, since candidate lists had already been drawn up and the interest was partly sparked by the position of women in these lists. This makes it remarkable that the share of women in parliament following these elections nevertheless increased by 5 percent. Although it is clear that the increase was partly due to the higher percentage of women deputies in the SPR-RSČ (Republican Alliance) and the opposition parties in general, including the ČSSD (Social Democratic Party) which made major gains, the phenomenon has still not been fully explained. After these elections the theme of women in politics remained on the pages of the press, but in somewhat sporadic form, and with no sign of movement towards deeper analysis or fuller information. It was at this point that the development of media 'discourse' on the question began to lag behind the trend of public opinion. It failed to reflect the increasing range of expert publications since 1996 [Vodrážka 1996a, b, Hauserová 1996], or even the fact that the problem of women in politics was now part of an agenda being internationally monitored in the context of Czech efforts to meet criteria for entry into the European Union. It was not until the end of 1997 that criticism of the media presentation of the problem and an attack on empty, purely rhetorical character of calls for more women in politics, first appeared in the mass print media [Šiklová 1998b].

In the Czech situation, of course, the very term 'discourse' can be used only with certain reservations. As far as discourse about women in politics is concerned, it is striking how rarely the subject generates real discussion. The authors of the articles analysed are almost always reacting to an event or opinion poll rather than to another presented view, and what they are delivering are more or less independent monologues. The result is that there has not yet been any genuine refinement of argument and so no shift in views of the problem. Another typical phenomenon is the tendentious use of expert opinions, in which professional qualifications are exploited to increase the apparent expert weight of a text without the people concerned having any specialised knowledge of the problem. Very frequently this leads to the legitimisation of commonplace prejudices and the manipulation of public opinion. Another striking aspect here is that the overwhelming majority of the 'experts' who have expressed themselves on the theme are psychologists, and it is to the psychologists that the media likes to turn. There has been hardly any input from sociologists and absolutely none from political scientists. One could therefore speak of the 'psychologisation' of a social and political theme, which corresponds to one feature already mentioned - the way that the thematisation of male and female psychological attributes has dominated in arguments on the subject.

There are also several cases of pure arrogance on the part of journalists. For example, Miroslav Korecký [1996: 2] commented on the wish of $70 \%$ of the population to see legislative measures taken to ensure higher female participation in politics with the following words: "A nation that had got used to having one or two women in every communist government is neurotic about the issue, and this allows the opposition to pick up 
points." In fact the first female minister in this country took office in Gottwald's government in the autumn of 1947 (before the Communist coup), and from 1970 to 1989 there was not a single woman in the government. Nor is there any evidence to support the claim that the opposition was "picking up points" on the basis of the question of women in politics. In their election platforms none of the parties played this card, and only in the ČSSD (Social Democratic Party) was there a hint of internal party discussion on the theme of quotas. The effect on the voters is likewise unknown and Korecký's claim is tendentious fantasy. His vocabulary also indicates a dismissive arrogance in relation to public opinion.

Another peculiarity of Czech discourse is reluctance to state real ideological positions. Conservatively orientated authors never openly reject the principle of political participation by women, but appeal to the practical reasons for low participation, such as care for children. Among such authors failure to make any links between the issue of women in politics and the real social problems of the female population is absolute, since they essentially speak of women's political careers as mere 'hobbies' that they can pursue if their husbands provide financial security [see for example Štětka 1995]. The authors who want more serious change and are also aware of the practical problems of women, have also, however, been shy of using any radical rhetoric about campaigns, strategies and so forth, obviously for fear of connotations of left-wing thought and social engineering. They too have been hiding behind the rhetoric of family values [see for example Brdečková 1994].

As far as the language of media discourse about women and politics is concerned, there is a distinct difference in the way information is provided about women politicians abroad, their successes, problems and even measures taken in foreign states to increase female representation. All such information is presented in a correct, objective way and without ironic comment, and is evidently taken over or excerpted from the foreign press without modification. Treatments of this theme in the Czech Republic, by contrast, and especially on the question of quotas, are rarely unbiased or solidly based. Our own politicians are very frequently collectively referred to as men or 'gentlemen' as if there were no women among them at all. Before the election of the Chairman of the Senate in 1996, for example, despite the fact that there was more than one female candidate, LN published an article with the headline "Who will be the Number Two Man?" ["Kdo..." 1996]. During this election there was also a case of the political abuse of female politicians and a cynicism that journalists copied without hesitation. In an article on the election headlined "The Best of the Worst", the rejection of the candidates Irena Ondrová and then Jaroslava Moserová was described in these terms: "ODS wanted to put at the head of the senate a person who - in the words of one member of the party leadership - will make the Senate a laughing stock in three months." [Holub and Mlynár 1996-1997]. The language of a short news report from Kroměřiž also unconsciously showed just how far female politicians are genuinely regarded as equal or natural: "In the Kroměříž region, all the candidates of any party who have any chance of a parliamentary seat are women. Their male colleagues are unable to explain why this has happened. But most of them don't mind." ["Na Kroměřížsku..." 1998].

It appears that there is also a difference in the way the media refer on the one hand to women in national state bodies and on the other to female mayors. The association of women with the world of high politics, which throughout the discourse is to a considerable extent regarded as an identification with power, clashes with the idea of femininity in 152 
a much more immediate way than it does in the case of the female mayors, whose energy, panache and capacity for problem-solving is associated with a care for others that is compatible with the idea of femininity. While the texts on female parliamentary deputies or ministers have a tendency to refer to the fact that they have not lost their 'femininity', in texts on mayors the properties usually attributed to men sometimes turn into the 'typically female', i.e. are associated with pragmatism and courage [for example Jirků 1997].

\section{Attitudes to Individual Aspects of the Question of the Political Participation of Women}

In the following pages I set out in detail the opinions, attitudes and arguments from the point of view of the first three categories set out above in the section on "Research Method".

\section{Why the theme is regarded as socially relevant}

This is not a theme that was opened up by any special 'event' (although the change in public opinion on the question of quotas undoubtedly gave an important impulse to discussion). It was simply that the strikingly low representation of women gradually began to bother the public. At the general level, the justification of the relevance of the theme has been relatively vague, with some authors merely asserting that it's a "bad thing for humanity" [Buchert, Lipold, and Pecháčková 1995]. (For more on this generally humanist motif see also links to arguments in Category 3.) Essentially, the awareness of the relevance of the theme seems to be indirect, mediated partly by comparisons with the situation abroad and the discovery that this was a field in which we were visibly lagging behind the advanced countries, and partly by the contrast between the low representation of women in politics and accepted ideas about the equality of the sexes, producing evident surprise at the disproportion between the high educational qualifications and professional skills of Czech women and their political marginality.

As far as motivation for regarding the issue as important is concerned, however, some more opportunistic and superficial considerations could be at work. One theory is that given the discontinuity and accidental character of new political careers, and also a sense of the need to give the right impression and keep in step with the outside world, the current slightly raised percentage of women in parliament could be a kind of 'alibi' - just that minimum level of 'alibi' appropriate to the last decade of the 20th century. Evidently, for example, there exists some kind of unwritten law that while women are to be found on candidate lists, the first woman candidate most often appears in the fourth or fifth place. One might argue that this is just a percentage high enough to 'soothe' the public into regarding the situation as acceptable rather than shameful. This is Petra Buzková's feeling about the current state of affairs: "In the Czech Republic we are now at the cross-roads. It is still unclear whether the women in 'high' politics represent selected exhibits in the Czech Potemkin village designed to get the country into Europe, or whether they reflect the relative maturity of the society." ["Vždy..." 1996].

\section{Explanations given for the low representation of women}

The results of public opinion surveys were summarised in one of the first longer media articles. The reasons put forward were the unwillingness of men to accept women as equal partners, the unwillingness of women themselves to engage in politics, the centuries-old traditions in the position of women, and finally the continuing perception of motherhood as the most fundamental female role, which women only exceptionally wish 
to give up [Buchert, Lipold, and Pecháčková 1995]. In articles published in the Czech media one can, however, find a whole range of other explanations, most of which offer insights more interesting than the standard explanations mentioned above. Unlike those standard interpretations, they usually have a less 'fatal' character and are often linked to criticism of the current political climate and the psychological characteristics of specific people on the political scene. My typology of views has been structured according to the factors individual authors regard as the reason for the low representation of women.

\section{a) An immature and masculine (macho) post-revolutionary political scene}

This factor is also regarded as determining factors b) and c), which directly relate to it. The primary cause is given as the rise of predatory young men. This explanation takes various forms. Psychologists point to the efforts of these men to stand out and make themselves visible, and the comic symbol of the phenomenon has been the purple jacket. In this context the psychologist Slavomil Hubálek has spoken of what he calls "postpubertal state" of Czech society: "The leading positions have been taken by predatory men whose activities are mainly centred on themselves. (...) Even top politicians are provoked by every little thing, taking offence, sulking, slandering and sending each other messages through the press" [cited by Brdečková 1994: 7]. Politician Jan Kalvoda formulated the same idea more cautiously, saying that "the year 1989 addressed men in politics", but rather than concentrating on psychological influences on the political scene he stressed its accidental quality. He argued that the status of women in politics is deformed by the fact that current political elites are a "community that was formed quite accidentally in 1989 or 1990 ", and did not exclude the possibility that the development of a more standard route from local to national politics may increase the proportion of women at the top [see Rabenseifnerová 1996]. Here the causal chain of male dominance is seen the other way round: "The low representation of women in parliament is regarded as entirely natural in a situation in which for the most part people are not reaching top positions by concentrated and purposeful work, but instead by a go-ahead style and sharp elbows" (Alena Gajdůšková, party secretary in [“Strany...” 1995]).

\section{b) The negative attitude of these particular men to women in politics}

The above diagnosis of contemporary male politicians is behind the view, expressed by Hubálek, that "it is no wonder that in such immature beings the mere presence of women awakens huge complexes: they cannot forget the way in which they were subordinated to women for so many years - in the family and at school. For this reason they revenge themselves and oust them from politics" [cited in Brdečková 1994: 7]. From the point of view of gender relations what we have here is the assumption that men were subject to a particular kind of gender oppression under communism in the form of loss of their dominant position or domestic authority. This is a motif that appears relatively frequently [Wagnerová 1996, Možný 1990, Tatur 1992 and others], and which is attributed to the feminisation of the educational system, among other things. In this context we would seem to be dealing with a specific legacy of communism, in which the political arena is becoming a field for the 'settling of gender scores'. On the other hand, such a view indirectly casts doubt on the thesis of the traditional idyllic 'solidarity of the sexes' in our society [as claimed, for example, by Šiklová 1998a].

Another variation on the same theme appears in an answer given by the Social Democrat Petra Buzková when asked whether Czech women were in the position of a 
minority (a question once again posed in relation to the issue of quotas): "At the level of political careers people sometimes draw attention to the negligible representation of women in political functions. It would not be wise, however, to confuse the state of Czech society with expressions of mean-mindedness in the current political coalition. (...) At the political level women don't need any special consideration. They simply need what we all need - that politics should become more cultivated." ["Vždy..." 1996].

\section{c) Women's distaste for working alongside these particular men}

According to Brdečková this situation influences the behaviour of women as well. She argues that "women are not too keen to be surrounded by the complex-ridden little lordlings on the parliamentary benches or ministerial chairs". [Brdečková 1994]. However courageous such psychological theories may appear to be, three years later they appear again in the following form: "women are always attracted to places where there are real men, and (...) there are practically no women in our political life, because there are no real men either. (...) The productions our gentlemen politicians have been putting on their stage for several years, are often, probably mostly, "competitive games for boys" [Př́hoda 1997]. This author generally attributes this state of affairs to the character of male socialisation, and the fact that 'our contemporary environment' offers little encouragement to men to grow up.

These theories are confirmed by some experiences of women in high political office with working in a male environment. "I repeatedly find that there are people who believe that because I am a woman, I can be shouted down by arrogance and bad language. I don't like confessing it, but occasionally the tactic has worked." (Buzková in ["Vždy..." 1996]). Politician Vlasta Parkanová noticed distrust and counter-pressures, the "stigma of the outsider'. To the question, "Can it be said that your arrival at the ministerial level was free of complications?" she said "Not at all. I don't want to play any cheap feminine card, but I can't say that anybody made any great efforts to help me at the beginning. (...) As far as the professional success was concerned, it was a big jump up for me, and I was immediately attacked on all sides, so that I wouldn't think it was a bed of roses..." [Spurný and Šídlo 1997].

A rather different variant is an explanation that appeals to the risky overall character of post-revolution politics: "Women are far less willing to take major risks than men. Naturally, men who take risks - in politics too - tend to be successful. Sometimes. They can also fail hopelessly. Women are far more aware of the responsibility they carry, and don't permit themselves the same risks as men when they are responsible for a certain group of people." (Buzková in [Buchert et al. 1995]). Prime Minister Zeman's explanation for absence of women in his new government involved a different variation on the same theme. He said that it was a government of 'suicides' and promised that women would have the chance to work in government positions successfully and 'without getting scratched' after two years [Kalenská 1998].

All the three factors just mentioned connect the immaturity of the political scene to the greedy monopolisation of political power by men. The causes are not presented in a one-sided way, but it must be pointed out that none of the authors have considered the historical advantage of these gentlemen's clubs, the value of experience with politics and power that they have gained, and the male solidarity that was, as it were, a christening gift to post-1989 Czech politics. While criticising the initial 'immaturity' of these men, the 
authors fail to see that they have now obtained a lasting head-start on any women in politics.

\section{d) It is a result of free competition or 'the survival of the fittest'}

This explanation is a mirror reflection of all the factors mentioned, since it is adopted precisely by the type of politician already described and by their admirers in the press. It is based on the belief that entry into politics is entirely a matter of free competition and the outcome must therefore be entirely just. "The representatives of the stronger sex have told women success in politics cannot be legislated for" and that "To claim that (the situation) is the result of some unjust discrimination against women is nonsense. There is not a single proof of any such discrimination. The number of women in politics is precisely the number that have managed to succeed in the relentless mills of the political parties" [Stoniš 1996]. Naturally, the skills that are measured in this competition are not precisely defined, although they must include the interest of men and their efforts to succeed, the lack of interest on the part of women, etc., i.e. exactly the factors that undermine the argument. Only Ivo Možný has explicitly opposed this type of 'explanation', writing that "It's hard to say whether there is something there [in our political parties] that would really attract an intelligent person with claims to personal dignity. But if a women nevertheless wants to try, she doesn't have an easy time. It's already a textbook cliché, the way that men construct their 'relentless mills' in order to protect the positions to which they so pathetically cling. For a women to succeed, she has to be twice as competent as a man. (...) In politics one important element of competence is the ability to appeal to voters. If ministers were appointed only on the basis of expertise, they wouldn't be appointed by a political party after elections. Capacity to appeal to voters includes such factors as where a candidate is from and gender" [Možný 1996]. To Stoniš's appeal to 'the laws of common sense', he replies that 'this is the kind of so-called 'common sense' that the creator seems to have given us for no better purpose than to enable us to enforce and justify our prejudices. It is something that has far more effect on the share of representation than quotas, which in fact no one has suggested" [ibid.].

\section{e) Liberal Fatalism or Liberalism without Problems}

Brdečková [1994] regards this idea of 'problem-free liberalism' as one of the causes of the low representation of women, since it provides a basis for the idea that everything is perfectly all right and the existing situation represents a satisfactory confirmation of alleged natural and personal capabilities. Moreover, this attitude rests ideologically on the priority of freedom and non-interference in the supposed 'natural' course of events. It is an attitude that for the most part is typical of female politicians as well, since it also provides a defence of their own personal success. One of its effects is to distance them from the perception of the problems of other women, since they are "satisfied with their own rarity" [Rolečková 1996].

\section{f) Female politicians have not proved their worth}

One of the few expressions of public misogyny and a typical example of sexism is generalisation from female individuals (usually caricatured) to the whole group. It can, however, be assumed that such opinions are held by the $50 \%$ of men (and approximately $16 \%$ of women) who according to a DEMA agency poll do not want a women in government, or by the approximately $15 \%$ of respondents who believe that "women do not belong in 
politics" or are "incapable" [see Buchert et al. 1995], and express these opinions with phrases such as "women are hen-brained" or "it's a job for men". "The main reason why there are so few women in the government and parliament here is bad example. The women who occupy high political positions, can be divided without exception into two groups. Most of them behave (...) quietly, warily and inconspicuously. (...) The remaining few names, to which television viewers already react (...) unfortunately do not provide an example that arouses enthusiasm for further experiments with the share of women in power." The examples given are Marie Noveská, and Zuzka Rujbrová, who is condemned for membership of the Communist Party, and Vlasta Parkanová, a highly successful politician to whose policies the author of the article is opposed [Huk 1997].

\section{g) The division of labour or gender models}

In this section I classify views that condemn existing gender models as outdated and confining, views that suggest they ought to be upheld, and views that see such models as something given and impossible to change. Brdečková, for example, refers these models with dissatisfaction: "At home men are often in the same position as women in politics: they are secondary (...) it is more a question of resignation than conscious division of labour" [Brdečková 1994]. It is relatively rare to find the view, quoted below, that the usual appeal to the priority of care for children is only an excuse, and what is more important is care for the man and the habit of staying in the background and supporting the man: "Why is it that ambitious and capable women whose children have flown the nest, and who are interested in political life - mature women in the forties or younger who are lucky enough to have a grandmother or supportive husband to take over the household are not trying to get into politics? (...) The biggest problem, of course, is that we are too fond of them [men]. When a man has required so much of our work and attention, and we have invested such a lot of energy in him, he ultimately has to be placed high on the value ladder, or else it would all seem pointless. (...) Let us love them, but not make them our life programme. When Czech women learn to concentrate on themselves, the doors of politics will open to them, which will represent a step forward towards real humanity." [Kučerová 1996].

\section{h) The absence of the necessary standard of living and spare time}

Appeal to this reason is strongly differentiated in terms of the polarisation of right-left.

The conservative attitude is expressed by the view that the reason for the low representation of women is 'economic'. "One great crime of communism was the fact that it forced women away from the family and into work. (...) Czech women are only gradually being released from this obligation, since male salaries are still insufficient to keep a whole family. (...) It is therefore not surprising that women either go into business or - if at all possible - stay at home with the children. For the moment the satisfaction of political ambitions has to be put on the back-burner." [Štětka 1995]. This attitude is remarkable for its complete disconnection from real female problems and neglect of the possibility that women in politics might help to solve them. Parkanová expresses a very similar view: "No female deputy has a chance of competing with her male colleagues if her children are not grown-up. Sometimes I have the feeling that certain feminists blame men for this situation, but it was ordained by nature - or God. I don't believe that women's rights in this society cannot be defended by men - the prosperity of women and men in society is interlinked. (...) But I can turn to representatives of women's movements who are call- 
ing for a higher representation of women in parliament, and tell them with a clear conscience that I don't have the feeling that women in parliament would suffer discrimination from their male colleagues. I believe that as the overall level of society improves and women are liberated from a great deal of drudgery, the percentage of women in legislative bodies will also rise." ["Otázka..." 1990]. A female reader enthusiastically agrees: "I believe that absurd calls for women to fight for equality with men are already things of the past. But I also believe that one day in the future there will be, among other things, financially accessible and well-functioning services that will allow all of us, women and men, to devote ourselves to family, the work I love, and to our own interests and pleasures." [Petrová 1990].

The communists consider that the low proportion of women in politics is connected to a situation in which the work burden of the majority of women at home and in employment has increased, so that they have little time for other activities ["Strany..." 1995]. This view of affairs indirectly refers to the impact of the transformation on women, given the existing division of labour, i.e. it suggests that far from a trend toward the gradual liberation of women from 'drudgery', mentioned by the right-wing women, the current situation has involved an increase in such work for 'ordinary' women. According to another view, women's special work obligations have been generally increasing because men devote more time to their jobs than before." [in Buchert et al. 1995]. To summarise, the existing gender division of labour according to these accounts is deepening, and not because women have chosen it, since they are not shedding obligations in the employment sphere and we know from sociological surveys that most women do not even want to give up work outside the home. At the same time these kinds of explanation are very speculative since they do not in fact rely on any analysis of whether it is true that fewer women actually engage in politics or simply remain in the position of grassroots party members or grey eminences.

\section{i) Czech women and discrimination}

"The main obstacle to the Northern model (of emancipation) here is (...) the fact that Czech women generally do not consider men antagonists and do not demand full equality" [Brdečková 1994]. We hear this diagnosis of Czech conditions relatively frequently, but in fact the attitudes of Czech women are more complex, and depend on an understanding of the term 'discrimination' that is narrower than the meaning current in western countries. In Czech society only direct, explicit and deliberate discrimination is recognised as such. According to a STEM agency survey, "the majority of women do not regard the fact that they are so little represented in political and public life as a discriminatory act." At the same time, however, both women and the majority of the public as a whole considers this state as one of 'inequality' - which is then discussed primarily in terms of the "high level of privileges" of men in politics [Haberlová 1993: 16].

\section{What reasons are given for the need for a higher representation of women}

\section{a) The enrichment of politics by positive female qualities or the 'female element'}

"A female element brings to politics certain elements, shades and themes that men are not capable of providing" (Havel in [Buchert et al. 1995]). This argument forms a kind of counterpart to the reasons of type $2 \mathrm{a}$, since it projects onto women the qualities that men in politics are alleged to lack. At the same time it is true that this gender ascription is generally shared even outside the political context and seems to be confirmed by the experi158 
ences of the first women politicians to have been active in high politics. It is worth mentioning that in this context less traditional qualities haven been attributed to women. $A$ better overall perspective, refinement and a sense of humour are associated with the female element: "Try to answer the question of how the government would look and above all behave if there were five or six women ministers (...) only women, it seems could bring a sense of perspective and decency back to politics and above all political disputes. And even a sense of humour. Gentlemen, let us admit it: we are behaving arrogantly and insolently, and it is we who are the hen-brains, not them." [Stránský 1997 on the TV discussion programme Sedmička with politicians V. Parkanová and V. Štěpová].

Positive female advantages have sometimes been expressed more philosophically: a critique of male communication based on Goethe's distinction between 'the man on the ground' (he can act but cannot see) and 'the man in the tower' (he can see but can only warn, not act), who together have to carry social responsibility, is presented by psychologist Zlata Hálová and juxtaposed with faith in the better qualifications of women to undertake such communication. "The 'tangling' of the processes that constitute the vita activa and the vita voluptaria is natural to me, I am not afflicted by that dichotomy between hunter and tower-dweller and I don't need to experience the variety of the phenomenal side of things (the world, ecology, the needs of the human being, the human being as a whole) as contradiction." She explains this in terms of female (maternal) experience of life. "I have the calm good humour and optimist faith of a women on the ground, since otherwise I could not love and give birth to children. (...) And I also have the perceptions, reflections and power of imagination of a women in the tower, which allows me to see what might harm the life of my children and the responsibility to protect them..." [Hálová 1996].

Other opinions expect women to bring to politics a traditionally defined femininity: "I regard women as guardian angels and life is impossible without them. Including politics." (Voleník in ["Ženy..." 1997]). "Women can bring to politics the dimension of the guardian of the hearth, and maintain warmth and light, a favourable climate." ([Kučerová 1996], inspired by the psychologist Matějíček: "Man breaks through and woman sustains".) "The woman politician differs from the male politician. The man is usually more theoretical and systematic, and has a tendency to regard politics as a science. Not that politics is not a science, but it is also, to a considerable extent, work with people. Women have more capacity for empathy, putting themselves in the position of others, and more imagination. They are often better able to sense the atmosphere and adapt themselves. This means that they are successful (...) particularly in foreign politics." (Burešová in [Buchert et al. 1995]).

Here it should be pointed out that this type of argument de facto expects that women will add something extra to politics, a kind of dowry or promise that they will really enrich politics - which truly equal beings would not, of course, have to give. As a result they are more severely judged. The authors of the statements mentioned have no awareness whatsoever that even their positive view of the matter could place obstacles in the way of women in public life.

\section{b) Faith in the harmonious complementary roles of men and women in politics}

This factor is not identical with the preceding one. It is based more on the idea of 'complete humanity' and 'complementary roles' in politics, and not on the need to correct it. In contrast to the preceding argument it stresses the equal weight of both sexes: "Only the 
combination of male and female ways of thinking produces a complete human being. Arguments from the lips of women are not often synthesising, but they are often very sharply analytic." (Hradská in [Buchert et al. 1995]). Otherwise, however, there is the same tendency to idealised projections. Nobody seems to doubt that the female and male element in politics will be harmoniously complementary: "In my view, the way that the male and female elements complement each other is very important and would also bring great benefits to Czech politics" (Burešová in [Buchert et al. 1995]). "The qualities of men and women, the good qualities, could complement each other in politics" (Buzková in [Buchert et al. 1995]). "And so if we are actually struggling for something, then we are struggling to develop this relationship of partnership at all levels. It is a desire for dual identity, partnership, and not a competitive desire. This is the specific character of what we call Czech feminism.” (Hradská in [Vodrážka 1996a]).

\section{c) In order that women should speak for themselves, not via men, and apply specific fe-} male experiences in politics

"Do it for me, Daddy!" This was the headline of Tereza Brdečková's pre-election article in which she argued that men in parliament would not defend women's interests, essentially because "nobody had said anything comprehensible to them on the question" about the nature, extent or consequences of women's problems. Nor, she said, could this be expected of them, since "despite all areas of equality, men and women represent two mutually such inaccessible worlds that it would be hard to require one to defend the interests of the other." Brdečková also acknowledges the existence of "a certain discrimination" against women, but "it is difficult to prove, because nobody wants to recognise it." As concrete examples of specifically female problems she cites such issues as the priority given to men in applications for top positions, the practice of insurance companies that refuse pregnant women travel insurance while accepting men with histories of heart attacks, and the recent attitude of male deputies to the 'morning after' pill RU 486 [Brdečková 1996]. "The absence of men in the family and women in politics has unpleasant consequences for both sides. In Parliament the deputies often debate social problems that can never effect ninety percent of them (...) questions of abortion or maternal leave can never affect men. (...) A person has to have lived through some situations to have any idea of how to improve matters. (...) Politics dictate living conditions to families, and for that reason improvement of the position of the family will not be achieved in the foreseeable future. Men also pay the price for the error: for their willingness to ignore the absence of women in public life, they are punished at home by the discontent of the 'guardian of the family hearth'." [Brdečková 1994].

This argument is the first and the only articulation of a female political agenda and its association with the question of the political representation of women. In public 'discourse' it has not yet found a response and thus remains atypical of Czech debate on the subject. For comparison we can mention the confirmation of Brdečková's view to be found in Norwegian experience, for example. The political scientist Hege Skjeie investigated whether members of parliament had the impression that the influence of women in politics had contributed to change in viewpoints inside the parties, and found that "reform of issues of care and care work [in the widest sense] is regarded as the most important contribution of female politicians in the present period. Care policy contains a series of political instruments by which the state plays an active role in organising and funding 
care for children in particular. In all parties these instruments have been stressed as central political matters." [Skjeie 1991: 241].

\section{d) Civic Freedoms and Democracy}

This type of argument does not focus on the political definition as a group, but on women as individual citizens. It refers to the generally unsatisfactory civic conditions of women: "to maintain civic freedoms and the survival of modern democracy, it is essential to devote continuous attention to ensuring increasing equality of opportunity for citizens to share in the political, social and economic life of society. And we have definitely failed to do all that we should to assure women an equal chance of career and free choice of role in life" [Rolečková 1996]. Eva Rolečková generally regards it as important "to think of ways of giving women space to make effective decisions on their own position, rather than merely listening to the decisions of gentlemens' clubs on the role that women want." [ibid.].

In her view 'pseudo-conservative proclamations' of the noble position women should occupy in the family, are a "typical example of the rejection of the family as the basic natural structures of society. If the family is to remain such a natural structure, then the division of roles within it should be determined without state or party indoctrination. And a family is created from a minimum of two adult beings: a man and a woman. The role of both is irreplaceable, and not simply the role of women" [ibid.]. This is Rolečková's reaction to the tendency since 1989 rhetorically to stress the family role of women. It is worth noting that such views are taken, paradoxically, by spokesmen of the one Christian parliamentary party.

It is this type of contribution, which appeared before the elections in 1996 when the theme of women in politics was opened up, that uses the framework of this 'discussion' to draw attention to the wider issues of the social position of women with the theme of 'woman and politics' playing the role of mediator.

\section{e) Anti-sexist example or 'missionaries'}

One completely isolated contribution refers to the role of publicly successful women who are changing the gender stereotype that prevents most women from succeeding (standing out). The author focuses on women who do not bring some ill-defined 'female element' to their work but are what he calls "our sheriffs" since they are exceptionally uncompromising and thorough in civic affairs. "But in our society, which suffers from poorly concealed anti-feminism just as from racism, every able woman in a public office is hugely important. She is worth a whole library of feminist books. She is a missionary." [Blažek 1997].

For a further three categories I shall simply summarise the most basic findings. Statements relating to the idea of active measures to encourage the political participation of women, are in general negative, and most strongly negative from the side of journalists, since it is precisely here that their ties to the political scene and neglect of the wishes of citizens is most apparent. It is also over the question of 'quotas' that there are the most striking examples of manipulation of data, ignorance and subsequent passing on of false information to readers, and even of arrogant dismissal of the sections of the population who express support for quotas. A positive image of the woman in high politics continues to depend on the woman's projection of 'success' in the family role, and female politicians themselves use this as a defence, minimising their political ambitions in their rheto- 
ric at least, and often presenting their careers as 'accidental' etc. This is not surprising given the frequently voiced fears of women becoming masculine in behaviour after entry into politics [see e.g. Šiklová 1992: 28]. Since the elections of 1998, discussion of women in politics has begun to show sign of decline to the frivolous 'folklore' level, for example in debate about who should be beauty queen of Parliament and the flirting in parliamentary circles. The image of female mayors (local politicians) in the media is more respectful and serious, although the success of women in local politics is still sometimes presented as if it were rather astonishing. The category of the image of the woman voter represents an entirely separate chapter, in that here there is praise for the political maturity of Czech women who, for example, almost never vote for right-wing extremists [Petráček 1996].

\section{Conclusions}

My analysis of the discussion of women in politics has highlighted two different but inter-related themes. One is the role of Czech intellectuals in the public articulation of a new theme of social debate, and the other is the nature of several gender stereotypes in contemporary Czech society.

In their attitude to the results of public opinion polls, the professional communicators have taken up ideological attitudes that reflect their primary orientation to the attitudes of politicians. The expert opinions to be found in the media have been taken almost exclusively from psychologists. So far the theme has been almost entirely ignored by political scientists, and only a few politicians have offered their views on the subject. Academics using approaches based on the concept of gender (feminists), have so far not entered mass media discourse, and this is largely because of the ideological character of Czech media space, in which the concept of politics has been deliberately narrowed and in which there is an anti-feminist bias. Women activists have also not entered the media discourse, since so far they are a relatively small group mainly focusing on questions of violence against women or commercial sexual exploitation of women. The theme of the political representation of women is very marginal to their interests.

Despite the limitations and bias of media discussion, it is interesting for the way in which it indicates an interesting trend in the perception of politics from the gender perspective, and also in the image of women as related to politics, i.e. in views of both 'gender in politics' and 'politics in gender'. The dissatisfaction of the public with the Czech political scene is acquiring a gender dimension, the specific content of which can be summarised as follows: men - immature and greedy for power, women - potentially more sensible but lacking self-confidence and without interest in power. In the context of calls for more women in politics, the traditional image of women has therefore been expanding and changing in remarkable ways. Not only are the professional capabilities of women more or less taken for granted, but there are expectations that women could bring to politics even attributes traditionally ascribed to mature manhood, such as rationality, courage or determination. At the same time, however, women in 'high politics' especially, are required to project traditional feminine qualities and aspirations. These very high expectations and demands of women politicians are associated with the primary orientation of discussion to the benefits women might bring to politics (cultivation and refinement), and neglect of the issue of the benefits politics might bring to women. As yet 
discussion has not shifted from the purely cultural level to the level of the theory of democracy or active citizenship, let alone the context of social policy.

Translated by Anna Bryson and Jana Klepetáčová

HANA HAVELKOVÁ is an associate professor at the Institute of Humanities, Charles University in Prague. She teaches sociology, political philosophy and feminist theory. She has edited the collections of articles entitled Lidská práva, ženy a společnost [Human Rights, Women and Society] (1992, in Czech), and Exituje středoevropský model manželství a rodiny? [Is there a Central European Model of Marriage and Family?] (1995 in Czech and German), and co-edited Žena a muž v médiích [Woman and Man in the Media] (1998 in Czech). Her articles in English include "Women in and after a 'Classless' Society" (1999, in Women and Social Class - International Feminist Perspective) and "Abstract Citizenship? Women and Power in the Czech Republic" (in Social Politics. International Studies in Gender, State and Society 2/3 1996). She is a member of the board of the International Association of Women Philosophers (IAPh).

\section{References}

Arendt, H. 1960. Vita activa oder Vom tätigen Leben. München: R. Piper and Co. Verlag.

Blažek, B. 1997. "Útěkářky?" [Deserters?]. Literární noviny, 22. 10. 1997: 3.

Brdečková, T. 1994. "Čekání na Libuši” [Waiting for Libuše]. Respekt 10.-16. 10. 1994: 7-9.

Brdečková, T. 1996. “Tatínku, nějak to tam zařid'”" [Daddy, Do It for Me!]. Lidové noviny, 23. 3. 1996: 2.

Buchert, V., J. Lipold, M. Pecháčková 1995. "Žena v politice” [Woman in Politics]. Magazín DNES, 28. 9. 1995: 26-30.

Haberlová, V. 1993. "Postavení žen v zemích střední Evropy. Česká republika" [The Position of Women in the Coutries of Central Europe]. (Projekt Rady Evropy). Survey Report. Praha: STEM - Středisko empirických výzkumů, listopad 1993.

Hálová, Z. 1996. "Muž na zemi, muž na věži a láhev vína" [Man on the Ground, Man in the Tower, and a Bottle of Wine]. Lidové noviny, 21. 9. 1996: 5.

Hauserová, E. (ed.) 1996. "Růže mezi trním. Ženy v politickém životě" [Roses Among Thorns. Women in Political Life]. Sborník ze semináře Ženy a politika, Praha 3.-5. 5. 1996. Zpravodaj Zeleného kruhu, Special Issue.

Havelková, H. 1996a. "Ženy v politice a ženská politika" [Women in Politics and Womens Politics]. Pp. 19-31 in Feministické rozhovory o "tajných službách”, ed. by M. Vodrážka. Praha: Nadace Gender studies.

Havelková, H. 1996b. "Český diskurs o ženách a politice před volbami 1996" [Czech Discourse on Women and Politics Before the 1996 Elections]. Aspekt no. 2: 83-88.

Hoecker, B. (Hrsg.) 1998. Handbuch Politische Partizipation von Frauen in Europa. Opladen: Leske und Budrich.

Holub, P., V. Mlynáŕ 1996-1997. "Nejlepší z nejhorších” [The Best of the Worst]. Respekt, 30. 12. 1996-5. 1. 1997: 2.

Huk, J. 1997. "Proč je u nás tak málo žen v politice" [Why There Are So Few Women in Politics]. Denni telegraf, 1. 4. 1997: 3.

Jirků, I. 1997. "Ženy v mezních situacích" [Women in Extreme Situations]. Magazín DNES, 27. 11. 1997: 16-20.

Kalenská, R. 1998. "ČSSD schválila Zemanovu "vládu sebevrahủ” [The Social Democrats Approved Zeman's 'Government of Suicides']. Lidové noviny, 20. 7. 1998: 1.

Kalnická, V. 1998. "Zapojení žen do politických funkcí” [The Involvement of Women in Political Functions]. Informace z výzkumu 98-05, ques. no. 46-48h. Praha: IVVM. 
"Kdo bude mužem číslo dvě" [Who is Going to Be the Man Number Two] 1996. Lidové noviny, 25. 11. 1996: 2.

Korecký, M. 1996. “Ženy v ofsajdu?” [Women Off-side?]. Lidové noviny, 18. 3. 1996: 2.

Kučerová, J. 1996. “Ženy v politice?” [Women in Politics?]. Zitřek. Časopis pro liberální politiku, no. 4: 8 .

Matland, R. E. 1999. "Legislative Recruitment: A General Model and Discussion of Issues of Special Relevance to Women." Paper for the International Conference on Women's Representation in Eastern Europe in Bergen May 28-29, 1999.

Možný, I. 1990. Moderní rodina. (Mýty a skutečnosti) [The Modern Family. Myths and Realities]. Brno: Blok.

Možný, I. 1996. “Zdravý rozum máme všichni, ale každý jiný” [We All Have Common Sense, but Each of Us a Different One]. MF DNES, 16. 7. 1996.

"Na Kroměřížsku kandidují samé ženy" [In the Kroměřiž-Region there are only Women Candidates] 1998. MF DNES, 12. 6. 1998: 2.

“Otázka pro poslankyni Federálního shromáždění Vlastu Parkanovou” [A Question for the Deputy Vlasta Parkanová] 1990. Lidové noviny, 20. 11. 1990.

Petráček, Z. 1996. "Kdyby nebylo žen...” [If There Were No Women...]. Respekt, 10.-16. 6. 1996: 2.

Petrová, M. 1990. “Reakce na Parkanovou” [Reaction to Parkanová]. Lidové noviny, 29. 11. 1990.

Pitrová, Z. 1998. "Petra Buzková ztratila korunu parlamentní královny krásy” [Petra Buzková has Lost her Crown of Miss Parliament]. Lidové noviny 11. 9. 1998.

Př́ihoda, P. 1997. "Proč je málo žen v politice" [Why There Are so Few Women in Politics]. $M F$ DNES, 6. 8. 1997: 11.

Rabenseifnerová, M. 1996. "Listopad 1989 oslovil muže. Rozhovor s Janem Kalvodou” [November 1989 Men Addressed. An Interview with the Politician Jan Kalvoda]. Lidové noviny, 1. 4. 1996: 2.

Rolečková, E. 1996. "Žena mezi rovnoprávností a rodinou” [Woman Between Equality and Family]. Lidové noviny, 25. 3. 1996.

Skjeie, H. 1991. "The Rhetoric of Difference. On Women's Inclusion into Political Elites.” Politics and Society 19: 233-263.

Spurný, J., J. Šídlo 1997. “Já ty koně neřídím. S ministryní spravedlnosti o nezávislosti soudců, drátování děr a katapultáži” [I'm not Holding the Reins. The Minister of Justice on the Independence of the Judges]. Respekt, 26. 5.-1. 6. 1997: 22.

Stoniš, M. 1996. "Zákony zdravého rozumu dostaly na frak" [The Laws of Common Sense Were Defeated]. MF DNES, 9. 7. 1996.

"Strany zákon o zastoupení žen ve sněmovně nechtějí" [The Parties do not Want a Law on the Representation of Women in Parliament] 1995. MF DNES, 18. 9. 1995.

Stránský, J. 1997. “Chvála žen” [In Praise of Women]. Lidové noviny, 31. 10. 1997: 20.

Šiklová, J. 1992. "Ženy a politika (konfrontace se západním feminismem)” [Women and Politics Confrontation with Western Feminism]. Prostor 5, no. 20.

Šiklová, J. 1998a. "Men and Women United for a Higher Purpose." Transitions. Changes in PostCommunist Societies 5: 34-35.

Šiklová, J. 1998b. "Volání po ženách v politice jsou jen fráze!" [The calls for Women in Politics are Mere Empty Cliches!]. Lidové noviny, 5. 1. 1998: 11.

Štětka, J. 1995. "Pouhé vábení ženy do politiky nepřiláká" [Mere Enticing will not Attract Women into Politics]. MF DNES, 28. 8. 1995: 6. 
Tatur, M. 1992. “Why Is There No Women's Movement in Eastern Europe?” Pp. 61-75 in Democracy and Civil Society in Eastern Europe (Selected papers from the Forth World Congress for Soviet and East European Studies, Harrogate 1990), ed. by Paul G. Lewis. Houndmills, Basingstoke: Macmillan Press Ltd.

Vodrážka, M. 1996a. Feministické rozhovory o "tajných službách” [Feminist Interviews on the 'Secret Services']. Praha: Nadace Gender studies.

Vodrážka, M. (ed.) 1996b. "Politika s ženami či bez žen?" [Politics With or Without Women?] (dokumentace semináře). Praha: Nadace Gender studies.

Voet, R. 1998. Feminism and Citizenship. London, Thousand Oaks, New Delhi: SAGE.

"Vždy mě potěší slušnost a ohleduplnost. 7 otázek pro Petru Buzkovou" [I am Always Pleased by Decency and Considerateness. 7 questions for Petra Buzková] 1996. Nový horizont, ř́jen 1996.

Wagnerová, A. 1996. "Emancipation and Ownership." Czech Sociological Review 4: 101-108.

“Ženy, vzhůru do politiky!” [Women, Forward to Politics!] 1997. Lidové noviny, 19. 12. 1997: 4. 